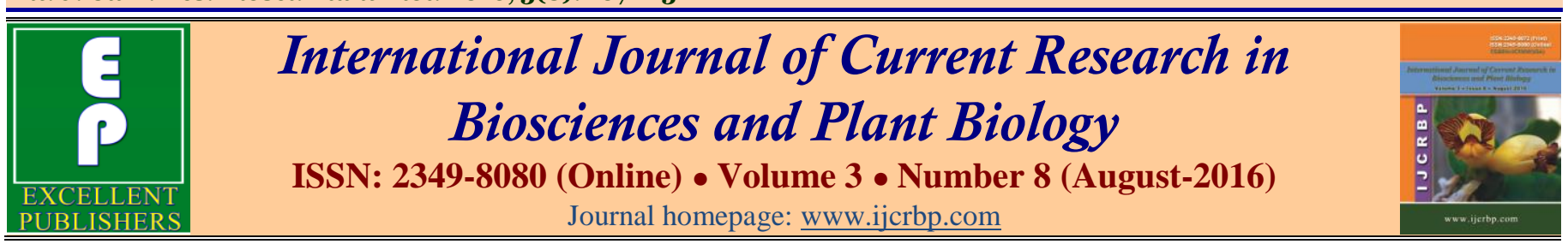

Original Research Article

doi: http://dx.doi.org/10.20546/ijerbp.2016.308.017

\title{
Assessment of Growth, Biomass and Productivity of Brassica campestris in an Agroforestry System in Nagal Hatnala Village, Dehradun (Uttarakhand), India
}

\author{
Rupinder Kaur ${ }^{*}$, Sanjeev Lal ${ }^{1}$ and Usha Bharti ${ }^{2}$ \\ ${ }^{1}$ Faculty of Botany, Uttaranchal College of Science and Technology, Dehradun (Uttarakhand) - 248 oo1, India \\ 2 PG Scholar Uttaranchal College of Science and Technology, Dehradun (Uttarakhand) - 248 oo1, India
}

*Corresponding author.

\begin{abstract}
A field survey was carried out in Nagal Hatnala village of Dehradun to evaluate the growth, biomass and productivity of Brassica campestris in an agroforestry system in Doon valley. Traditional agri-horti-silviculture system comprised of where fruit, fuel and fodder trees were present along with intercrops at the boundaries. The trees present were Toona ciliata, Mangifera indica, Bombax ceiba, Eucalyptus tereticornis, and Dalbergia sissoo. Agroforestry is a common practice in the Doon valley. Farmers are inclined towards retention of fruit based tree on their agricultural fields for addition monitory gains from the fruits and therefore agri-horticultural practices is the priority of high land holding farmers as the climatic and geographical situation also permit such practices. The study concludes that there was a significant reduction of agricultural productivity (grain, straw, and biological yield) under trees as compared to sole agricultural systems Sole crop showed maximum grain yield $(26.45 \mathrm{Mg} / \mathrm{ha})$ and straw yield $(18.97 \mathrm{Mg} / \mathrm{ha})$. Both grain and straw yield were 3.0 times and 2.94 times more in sole crop in comparison to crop growing under trees. Biomass of different plant components was in the order of shoot>silique>leaf>root i.e., $25.30 \mathrm{Mg} / \mathrm{ha}, 10.56 \mathrm{Mg} / \mathrm{ha}$, $8.83 \mathrm{Mg} / \mathrm{ha}$ and $7.07 \mathrm{Mg} / \mathrm{ha}$ respectively. Data on yield attributes and biomass showed statistically significant variation between crop growing as sole and under trees.
\end{abstract}

\section{Article Info}

Accepted: 26 July 2016

Available Online: 06 August 2016

Keywords

Agroforestry system

Brassica campestris

Grain yield

Harvest index

Productivity

\section{Introduction}

The Indian Himalayas represent $18 \%$ of the India's land area. It occupies a special place in the mountain ecosystem of the world. This region is important not only from the standpoint of climate and but also as a provider of life. It fulfills the water requirement of a large part of the Indian subcontinent and also harbors a variety of flora, fauna, human communities and cultural diversity. Agroforestry is a management system that integrates trees on farms and in the agricultural landscape. It leads to a more diversified and sustainable production system and provides increased social, economic, and environmental benefits for land users at all levels (Sanchez, 1995; Leakey, 1996; Fay et al., 1998). The agri-silviculture is very common practice by the farmers of Uttarakhand region which includes cultivation of agricultural crops in association of forest trees present in the fields. In hilly areas the existence without agro forestry is difficult because trees not only supplement the fodder, fuel, fibre, fruits etc. but also reduces the pace of land sliding in the fields, protect crops adverse wind and climatic condition, conserve the moisture, improve the soil quality through nitrogen fixing and organic matter in terms of litter fall etc. Therefore planting of trees along with crops improves soil fertility, controls and prevents soil erosion; controls water logging, 
increase local biodiversity, decrease pressure on natural forests for fuel and provide fodder for livestock (Makundi and Sathaye, 2004). The integration of trees on the farmland creates a complex biological interaction, which may not necessarily result in yield advantage. The tree architecture plays an important role in deciding the growth of understory crops. The crown spread affects not only soil properties and micro site environment, but also the performance and yield potential of associated crops. Reports are available where the positive and/ or negative impacts of the presence of tree canopies on the performance of under storey vegetation have been indicated (Huxley et al., 1989; Kessler, 1992; Ong et al., 1991; Puri and Bhargwa, 1992; Lakshmma and Rao, 1996; Rao et al., 1998 and Gillespie et al., 2000; Thakur and Dutt, 2003).

Due to difference in growth pattern and resource requirement of trees and crop components, interaction among the components will be obviously complementary/facilitative or competitive. The complementary interactions increase overall productivity of a system, while competitive reduces the same. Under some circumstances, the crop productivity is lower under tree canopies (Grossman et al., 1980 and Puri et al., 1994); where as in other instances productivity is higher (Belsky et al., 1989; Puri and Kumar, 1995). The increased productivity of crops under tree canopies is attributed due to increased fertility of soil, improving microclimate, soil and moisture conservation under trees, while decreased productivity is due to shade and competition for light, moisture and nutrients (Walker et al., 1986; Schroth, 1999).

Brassica campestris is a herbaceous plant with an erect, branched stem up to $1.0 \mathrm{~m}$ tall, with a taproot reaching $60-80 \mathrm{~cm}$ in depth, lower leaves petioled, green, sometimes with a whitish bloom, ovate to obovate, variously lobed with toothed or frilled edges; upper leaves sub entire, short and petioled, constricted at intervals, sessile. The flowers consist of four yellow petals arranged in a cruciform manner. Plants are generally harvested before fruits are fully ripe to reduce shattering. The growing period varies from 40-60 days depending on the variety and weather conditions. Indian mustard is a cool-season vegetable, growing well at monthly average temperatures ranging from 15 to $18^{\circ} \mathrm{C}$. It can tolerate annual precipitation of about 500 to 4,200 $\mathrm{mm}$, annual temperature of 6 to $27^{\circ} \mathrm{C}$ and $\mathrm{pH}$ of 4.3 to 8.3. Mustards generally perform best in cool growing conditions and are a potentially valuable cover crop in open niches in early spring or fall in temperate climates.
Research findings indicate that modern agroforestry systems can be environmentally friendly and economically profitable. The association of high quality timber or multipurpose trees with arable crops and/or grazed pastures may i) improve the sustainability of farming systems, ii) increase resource capture and system yield, iii) diversify farmer's incomes, iv) provide new products to the wood industry, and v) may enhance biodiversity and create novel landscapes of high value (SAFE 2004). Studies on tree crop interaction are very vital for prescribing suitable agroforestry models in hilly regions like Uttarakhand. Keeping in view, the present investigation is an effort to examine productivity of Brassica campestris in an existing agri-silvicultural system in Doon valleys of Uttarakhand.

\section{Materials and methods}

\section{Study site}

The study was carried out in the Dehradun district of Uttarakhand, which is located between $28^{\circ} 43^{\prime}-31^{\circ} 27^{\prime}$ $\mathrm{N}$ latitudes and $77^{\circ} 34^{\prime}-81^{\circ} 02^{\prime} \mathrm{E}$ longitudes (Fig. 1). The river Tons separates the state from Himachal Pradesh in the north-west, whereas the river Kali separates it from Nepal in the east. The region, being situated centrally in the long sweep of the Himalaya, forms a transitional zone between the per-humid eastern and the dry to sub-humid western Himalaya. Nagal Hatnala is a village Panchayat in Raipur Tehsil in Dehradun district of Uttarakhand state, India. It is located $6 \mathrm{~km}$ towards East from District headquarters Dehradun. The Nagal Hatnala village is located in the UTC 5.30. Google map of study site is given in Fig. 2.

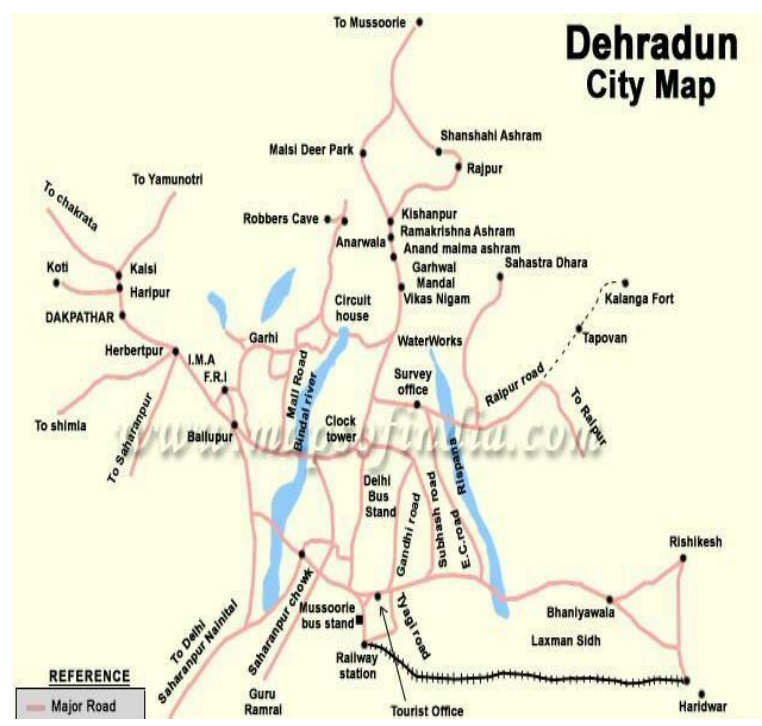

Fig. 1: Location map of Dehradun district, Uttarakhand. 


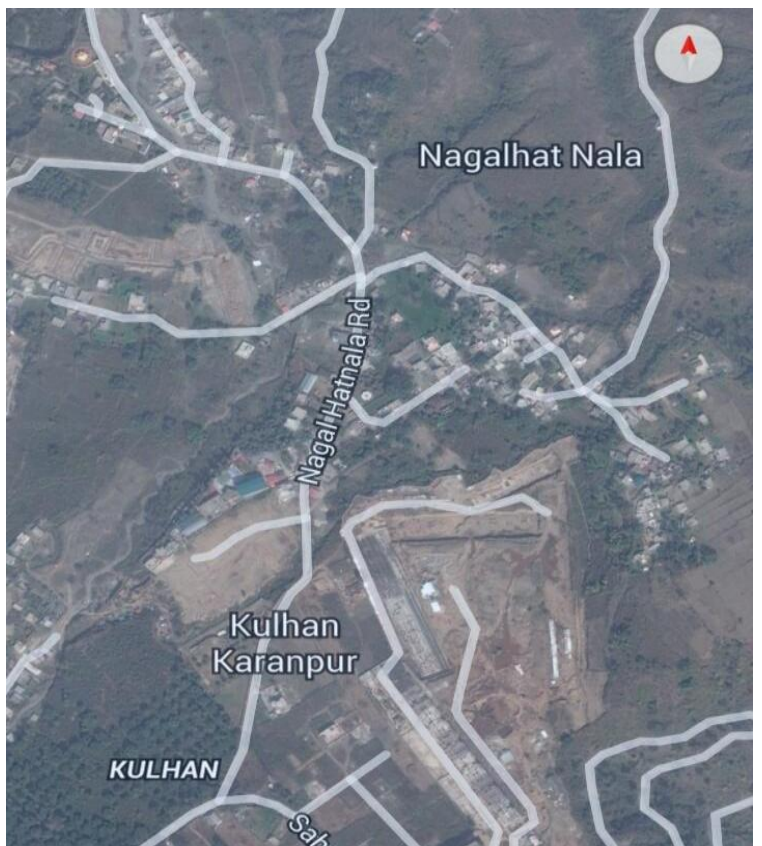

Fig. 2: Google map showing study site.

Estimation of growth, biomass and productivity of Brassica campestris

Total area of $10 \times 10 \mathrm{~m}$ size was selected for the present study adjoining with 11 trees namely: Toona ciliata, Mangifera indica, Eucalyptus tereticornis, Bombax ceiba, Dalbergia sissoo and Grewia optiva. Five quadrates of $50 \times 50 \mathrm{~cm}$ in triplicates were laid randomly which were site 1 (control), site 2 , site 3 , site 4 and site 5 for the growth and biomass estimation of Brassica campestris. Crop from the laid quadrates was harvested at the time of maturity and separated into grain (seeds) and straw. Crop height, number of shoots and number of leaves were taken immediately after plant was uprooted at the time of harvesting. Fresh and dry weight of Brassica campestris was taken following formula given below.

Moisture content (MC) was calculated as:

$$
\text { Moisture content }(\%)=\frac{\text { Fresh weight }- \text { Dry weight }}{\text { Fresh weight }} \times 100
$$

Biomass was calculated as follows:

$$
\text { Biomass }=\frac{100 \times \text { Fresh weight }}{100+\text { Moisture content }}
$$

Threshing and cleaning of the seeds was done manually, number of grains per plant were counted and weighed. Grains and straws were dried under shade to obtain net yield ( $\mathrm{Mg} / \mathrm{ha})$ of the crops. The average grain yield and straw yield was determined. Harvest index (HI) was calculated using the following formula given by Khandakar (1985):

Harvest index $=\frac{\text { Grain yield }}{\text { Biological yield }(\text { grains }+ \text { straw })} \times 100$

\section{Statistical analysis}

Average of data on growth and biomass was taken from the measurements of five sites in triplicates and the standard error was calculated. Data on growth, biomass and productivity of crops (sole and under agroforestry) were also statistically analyzed using Duncan's multiple range test (DMRT) at $p<0.05$. In order to verify statistically the significance level in different studied parameters, null hypothesis $\left(\mathrm{H}_{0}\right)$ was postulated that there is no significant difference due to different sites between crops growing as sole and with trees, and assumed that there is no significant difference in parameters studied like growth, biomass and productivity in crop (sole and under trees).

\section{Results and discussion}

This study was aimed to analyze the productivity of Brassica campestris as intercrop under Toona ciliata, Bombax ceiba, Eucalyptus tereticornis, Grewia optiva, Mangifera indica, and Dalbergia sissoo based traditional agroforestry system. Productivity of Brassica campestris under traditional agroforestry system along with trees was evaluated. The morphological parameters of Brassica campestris grown as a sole crop and along with trees are presented in Table 1. Average Plant height in different sites varied from 51 to $84.33 \mathrm{~cm}$. It was maximum in site $\mathrm{S} 3(84.33 \mathrm{~cm})$ and minimum in site $\mathrm{S} 5$ $(51 \mathrm{~cm})$ as given in Fig.3. Number of leaves as well as number of silique was highest in control site 32.16 and 264.87, and minimum in site S5 (18.94) and site S4 (72.26), respectively as shown in Fig. 4 and Fig. 5. Number of grains was also maximum in control site (914.16) and minimum in site S5 (244.77) as given in Fig. 6.

Gain yield reduced near the tree base and it gradually increased with an increase in distance from the tree. Fig.7 showed that grain yield was maximum in control (26.45 Mg/ha) and minimum in site S4 (8.81). Grain yield was 3.0 times more in control as compared to other sites studied. Crop without trees showed maximum straw yield $(18.97 \mathrm{Mg} / \mathrm{ha})$ as compared to site S5 which had 
minimum straw yield of $6.44 \mathrm{Mg} / \mathrm{ha}$. It was 2.94 times more in control as given in Fig. 8. Harvest index was maximum in site S5 (63.89\%) and minimum in site S2 (54.99\%). It was 1.61 times more in site S5 as compared to other studied sites as shown in Fig. 9. It is pertinent to mention that there was statistical variability between four sites and sole crop for plant height, number of leaves per plant, number of silique per plant, number of grains per plant, grain yield and straw yield except for harvest index as evident from Table 1.

Table 1. Growth and yield attributes of Brassica campestris grown under agroforestry system.

\begin{tabular}{|c|c|c|c|c|c|c|c|c|}
\hline Sites & $\begin{array}{l}\text { Plant } \\
\text { height }(\mathrm{cm})\end{array}$ & $\begin{array}{l}\text { Crop } \\
\text { density } \\
\left(\mathrm{m}^{-1}\right)\end{array}$ & $\begin{array}{l}\text { No. of } \\
\text { leaves per } \\
\text { plant }\end{array}$ & $\begin{array}{l}\text { No. of } \\
\text { silique per } \\
\text { plant }\end{array}$ & $\begin{array}{l}\text { No. of grains } \\
\text { per plant }\end{array}$ & $\begin{array}{l}\text { Grain yield } \\
\text { (Mg/ha) }\end{array}$ & $\begin{array}{l}\text { Straw yield } \\
\text { (Mg/ha) }\end{array}$ & $\begin{array}{l}\text { Harvest } \\
\text { index } \\
(\%)\end{array}$ \\
\hline S1(Control) & $79.33 \pm 2.1 \mathrm{a}$ & $2.0 \pm 0.01 \mathrm{~d}$ & $32.16 \pm 1.4 \mathrm{a}$ & $264.87 \pm 45.9 a$ & $914.16 \pm 269.1 \mathrm{a}$ & $26.45 \pm 0.01 \mathrm{a}$ & $18.97 \pm 0.01 \mathrm{a}$ & $58.52 \pm 1.1 \mathrm{a}$ \\
\hline S2 & $64.69 \pm 5.2 b$ & $3.0 \pm 0.05 \mathrm{a}$ & $26 \pm 2.3 b$ & $78.27 \pm b 9.5$ & $351.86 \pm 50.6 b$ & $10.62 \pm 0.01 \mathrm{~d}$ & $8.64 \pm 0.01 \mathrm{c}$ & $54.99 \pm 2.4 \mathrm{a}$ \\
\hline S3 & $84.33 \pm 2.2 \mathrm{a}$ & $2.0 \pm 0.01 \mathrm{~d}$ & $31.5 \pm 2.3 \mathrm{a}$ & $134.16 \pm 15.1 \mathrm{~b}$ & $429.33 \pm 79.4 b$ & $17.8 \pm 0.01 b$ & $12.28 \pm 0.01 b$ & $59.64 \pm 5.6 \mathrm{a}$ \\
\hline S4 & $62.22 \pm 3.4 b$ & $2.67 \pm 0.3 b$ & $24.83 \pm 1.3 b$ & $72.26 \pm 16.0 b$ & $251.11 \pm 32.3 b$ & $8.81 \pm 0.01 \mathrm{e}$ & $6.48 \pm 0.01 d$ & $57.30 \pm 2.3 \mathrm{a}$ \\
\hline S5 & $51.0 \pm 2.6 \mathrm{c}$ & $2.33 \pm 0.3 c$ & $18.94 \pm 0.2 c$ & $82.16 \pm 10.9 b$ & $244.77 \pm 14.5 b$ & $11.60 \pm 0.01 \mathrm{c}$ & $6.44 \pm 0.01 \mathrm{e}$ & $63.89 \pm 2.7 \mathrm{a}$ \\
\hline Mean & 68.31 & 2.4 & 26.69 & 126.34 & 438.24 & 15.05 & 10.56 & 58.87 \\
\hline
\end{tabular}

Values are Mean \pm standard error; Note S1 (Control) - Site 1 without trees, S2, S3, S4 and S5 are sites with trees; Values in the column followed by different letter $(s)$ are significantly different $(p<0.05)$ according to DMRT.

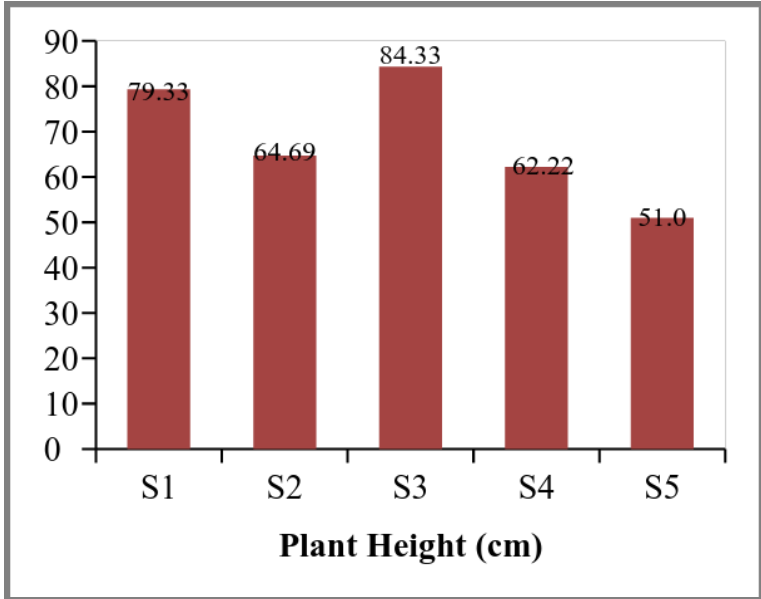

Fig. 3: Height of Brassica campestris grown under agroforestry system.

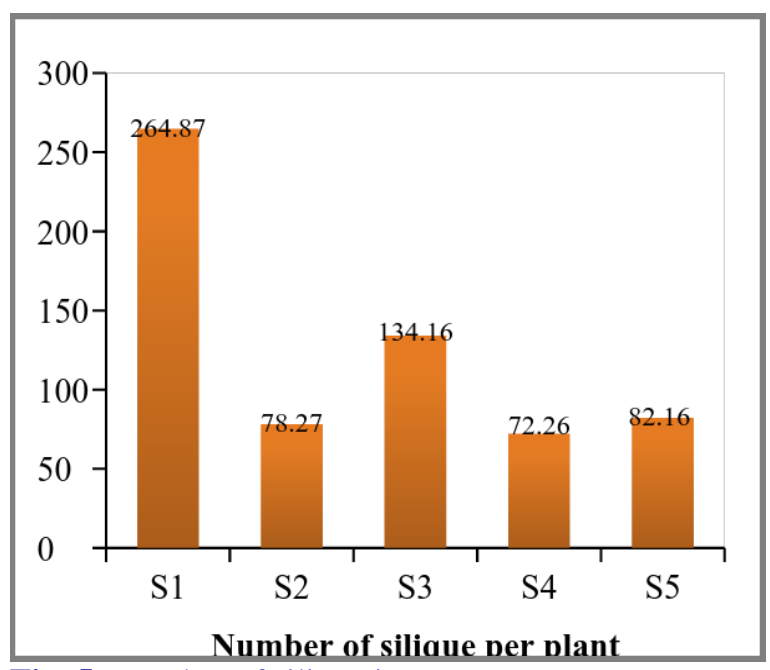

Fig. 5: Number of silique in Brassica campestris grown under agroforestry system.

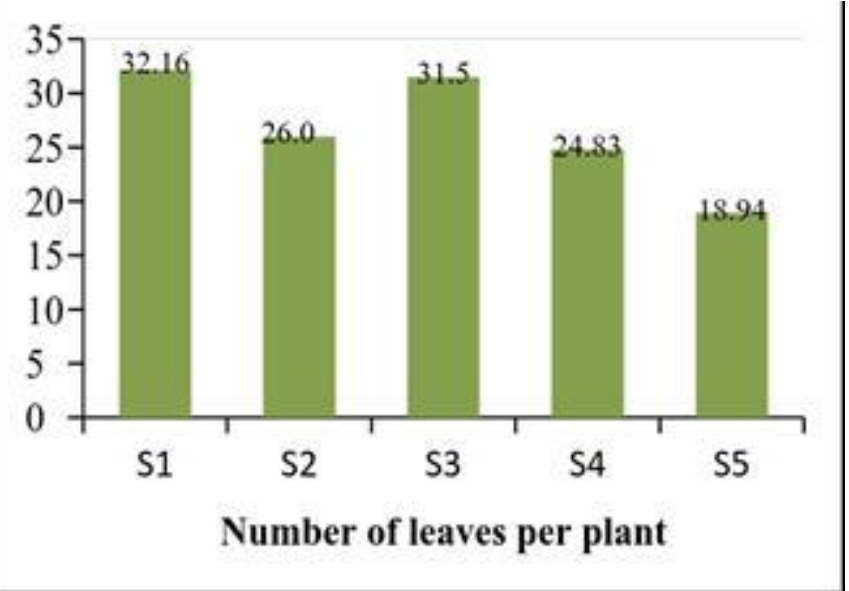

Fig. 4: Number of leaves of Brassica campestris grown under agroforestry system.

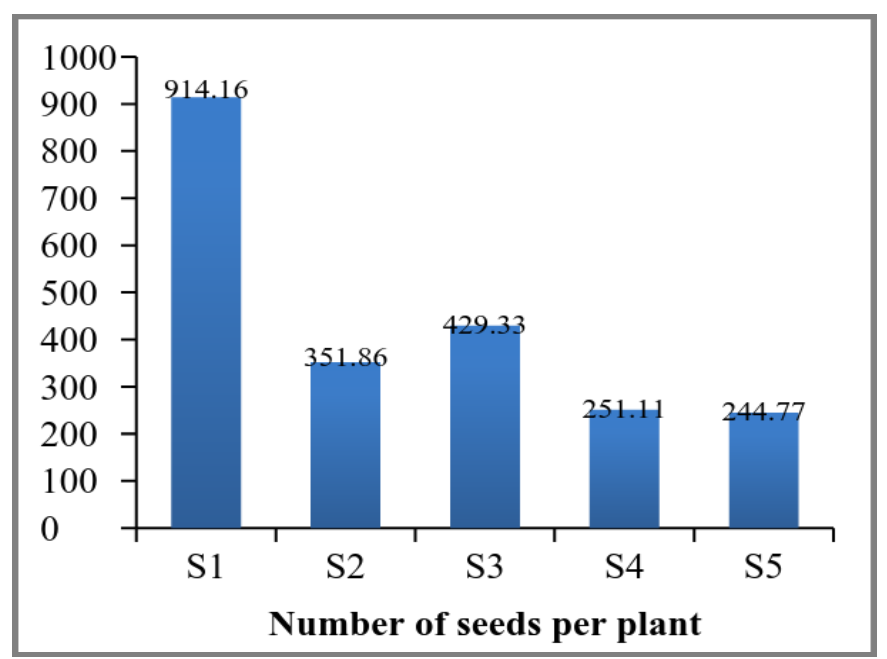

Fig. 6: Number of seeds in Brassica campestris grown under agroforestry system. 


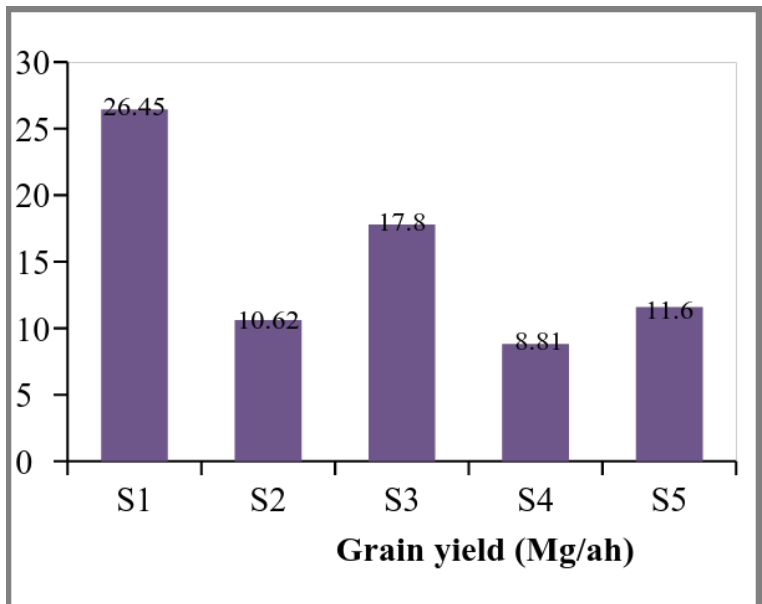

Fig. 7: Grain yield of Brassica campestris grown under agroforestry system.

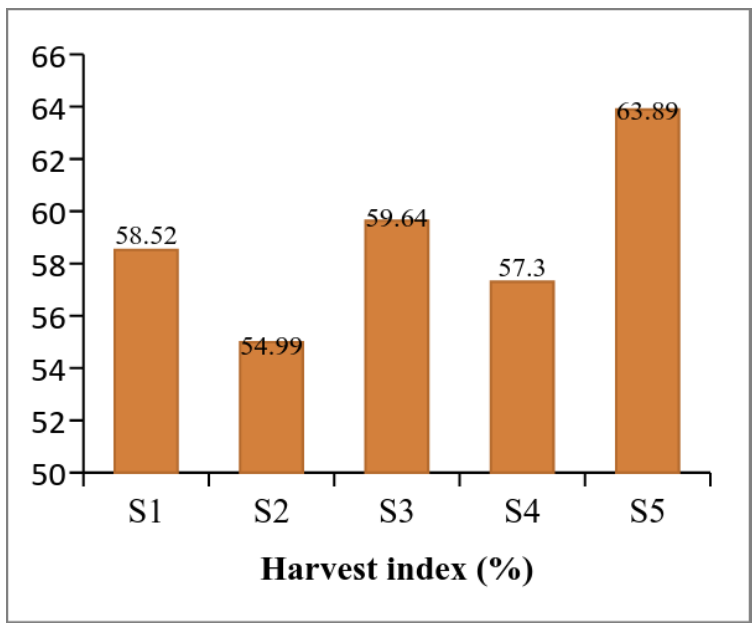

Fig. 9: Harvest index of Brassica campestris grown under agroforestry system.

Brassica campestris grown as sole crop and with trees showed that crop growth and productivity was more in sole crop in comparison to other sites where crop was growing under trees. Possible reason could be due to reduced availability of light, competition for below ground resources namely water and nutrients (Kohli et al., 1992; Bhardwaj, 1993; Kushwaha and Mathur, 1995). Reduction in grain yield and straw yield under trees can also be due to reduced availability of photo synthetically active radiations to crops because the rate of biomass production in many crops has been found to be proportional to the intercepted radiations (Boscae and Gallagher, 1977). Kohli et al. (1996) also evaluated the performance of different crops (Triticum aestivum, Cicer arietinum, Lens culinaris, Avena sativa, Trifolium alerandrum, Brassica campestris and Pisum sativum) under 6 year old Populus deltoides plantation. Germination, plant height, biomass and relative growth

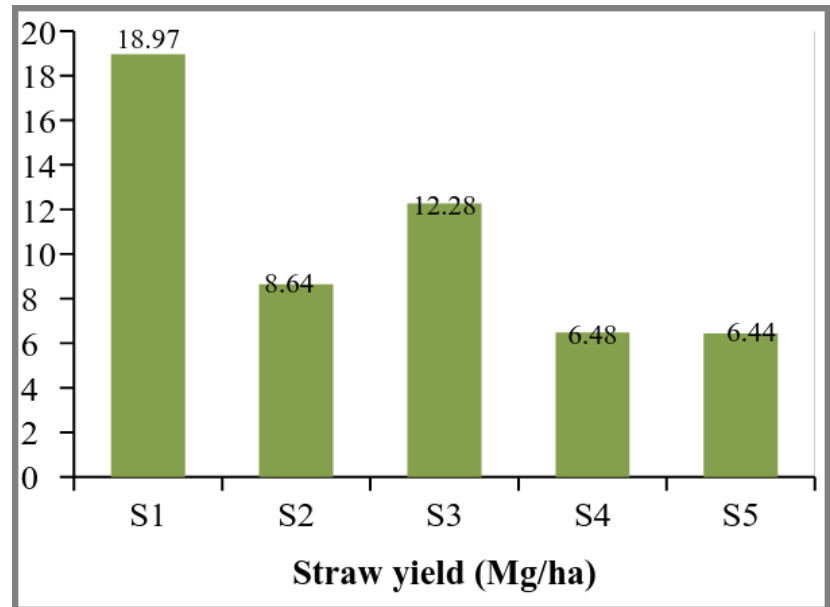

Fig. 8: Straw yield of Brassica campestris grown under agroforestry system.

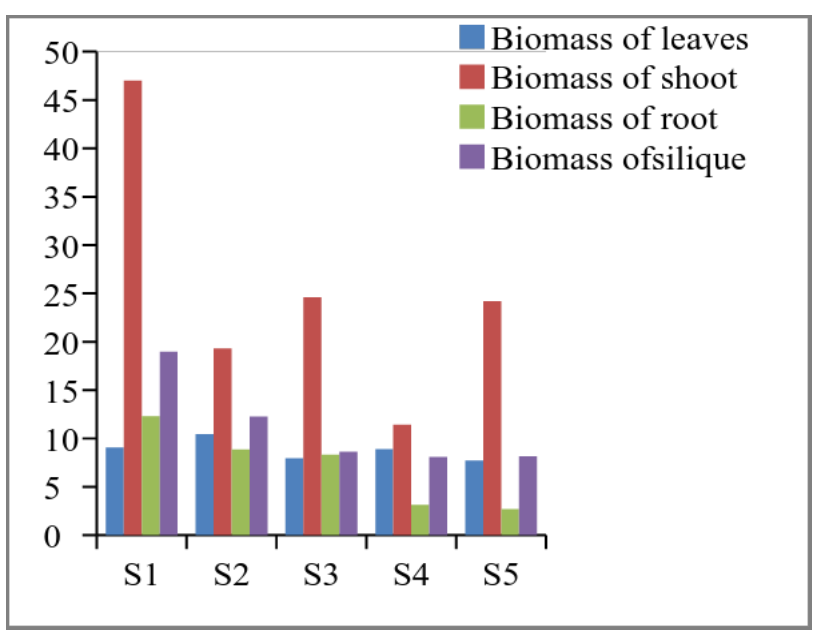

Fig. 10: Biomass of Brassica campestris grown under agroforestry system.

rate of crops were significantly reduced under Populus deltoides plantation compared with sole crops (without trees). The yield variations in different crops under agrisilvicultural systems were also noticed by several workers (Puri et al., 2002; Kumar, 2004; Swamy and Puri, 2005). It has been well documented that trees become more competitive with time and reduces crop yield (Rao et al., 1998). Yadav et al. (1993) also reported that the density in the mustard crop was declined with increasing tree canopy depth towards the tree stem. It was reduced up-to $9 \mathrm{~m}$ from the stem under irrigated and up-to $8 \mathrm{~m}$ under rain-fed condition compared with $21 \mathrm{~m}$ distance from the tree base in an open field (control). Bijalwan (2011) also concluded that under agri-horti-silvicultural system the biological yield of agriculture crops was $4913 \mathrm{~kg} / \mathrm{ha} /$ year with the reduction of 29.53 per cent as compared to the sole agriculture crops $(6981 \mathrm{~kg} / \mathrm{ha} / \mathrm{year})$. The economic 
yield of agriculture crops under AHS system as 1326 $\mathrm{kg} / \mathrm{ha} /$ year with a reduction of $45.05 \%$ compared to the sole agriculture crops $(2471 \mathrm{~kg} / \mathrm{ha} /$ year $)$. Under AHS system, the straw yield of agriculture crops is 3587 $\mathrm{kg} / \mathrm{ha} /$ year as compared to $4510 \mathrm{~kg} / \mathrm{ha} /$ year in sole agriculture crops.

Table 2. Biomass attributes of Brassica campestris grown under agroforestry system.

\begin{tabular}{llllll}
\hline Site & $\begin{array}{l}\text { Leaf biomass } \\
\text { (Mg/ha) }\end{array}$ & $\begin{array}{l}\text { Shoot biomass } \\
\text { (Mg/ha) }\end{array}$ & $\begin{array}{l}\text { Root biomass } \\
(\mathbf{M g} / \mathbf{h a})\end{array}$ & $\begin{array}{l}\text { Silique biomass } \\
\text { (Mg/ha) }\end{array}$ & $\begin{array}{l}\text { Total } \\
\text { biomass }\end{array}$ \\
\hline S1 & $9.08 \pm 0.11 \mathrm{~b}$ & $47.0 \pm 2.55 \mathrm{a}$ & $12.32 \pm 0.42 \mathrm{a}$ & $18.97 \pm 0.01 \mathrm{a}$ & 87.37 \\
S2 & $10.47 \pm 0.14 \mathrm{a}$ & $19.32 \pm 0.38 \mathrm{~d}$ & $8.86 \pm 0.76 \mathrm{~b}$ & $8.64 \pm 0.01 \mathrm{c}$ & 47.29 \\
S3 & $7.96 \pm 0.11 \mathrm{~d}$ & $24.6 \pm 2.55 \mathrm{~b}$ & $8.32 \pm 0.42 \mathrm{~b}$ & $12.28 \pm 0.01 \mathrm{~b}$ & 49.53 \\
S4 & $8.92 \pm 0.10 \mathrm{c}$ & $11.43 \pm 2.63 \mathrm{c}$ & $3.15 \pm 0.59 \mathrm{c}$ & $6.48 \pm 0.01 \mathrm{~d}$ & 53.16 \\
S5 & $7.74 \pm 0.11 \mathrm{~d}$ & $24.19 \pm 1.44 \mathrm{~b}$ & $2.70 \pm 0.32 \mathrm{~d}$ & $6.44 \pm 0.01 \mathrm{e}$ & 41.07 \\
Mean & 8.83 & 25.30 & 7.07 & 10.56 & 55.68 \\
\hline
\end{tabular}

Values are Mean \pm standard error; Note S1 (Control) - Site 1 without trees, S2, S3, S4 and S5 are sites with trees; Values in the column followed by different letter $(\mathrm{s})$ are significantly different $(p<0.05)$ according to DMRT.

Biomass of different components in Brassica campestris is given in Table 2. Biomass of different plant components was in the order of shoot>silique> leaf $>$ root i.e., $25.30 \mathrm{Mg} / \mathrm{ha}, 10.56 \mathrm{Mg} / \mathrm{ha}, 8.83 \mathrm{Mg} / \mathrm{ha}$ and 7.07 $\mathrm{Mg} / \mathrm{ha}$ respectively. There was statistically significant variation in the biomass among control site (S1) and other four sites. Fig. 10 shows that leaf biomass of Brassica as intercrop was maximum in site S2 (10.47 $\mathrm{Mg} / \mathrm{ha})$ and minimum in site S5 $(7.74 \mathrm{Mg} / \mathrm{ha})$. The shoot biomass was recorded maximum in control site (47.0 $\mathrm{Mg} / \mathrm{ha})$ and minimum in site $\mathrm{S} 4(11.43 \mathrm{Mg} / \mathrm{ha})$. It was also observed that the root biomass in site S1 (12.32 $\mathrm{Mg} / \mathrm{ha}$ ) was maximum as compared to site S5 (2.70 $\mathrm{Mg} / \mathrm{ha}$ ). In the site $\mathrm{S} 1$, the biomass of silique is maximum i.e. (18.97 Mg/ha) as compared to the other studied sites. Kaur and Puri (2013) also reported that sole crop had more biomass in comparison to crop grown under trees. They reported that total biomass of crop with trees was $33.34 \mathrm{Mg} / \mathrm{ha}$ whereas for sole crop it was 38.19 $\mathrm{Mg} / \mathrm{ha}$ in Vigna mungo and also in Triticum aestivum the total biomass for sole crop was $79.25 \mathrm{Mg} / \mathrm{ha}$ whereas crop with trees showed $74.63 \mathrm{Mg} / \mathrm{ha}$ biomass. Null hypothesis for growth, biomass and yield attributes in Brassica campestris is rejected as there is a significant variation between crops growing as sole and under trees.

\section{Conclusion}

Agroforestry is a common practice in the Doon valleys. Farmers are inclined towards retention of fruit based tree on their agricultural fields for addition monitory gains from the fruits and therefore agri-horticultural practices is the priority of high land holding farmers as the climatic and geographical situation also permit such practices. Present study concludes that there is a significant reduction of agricultural productivity (grain, straw, and biological yield) under trees as compared to sole agricultural systems but the overall return from tree-crop combinations is higher. Therefore, the agri-horticultural based cropping patterns needs to be strengthened in this Doon valley region. Agroforestry systems' existing in Doon valleys plays a significant role for fulfilling the basic needs of the rural community. Agroforestry based land use systems promote the sustainable alternative livelihood, improve soil quality, and empower the rural community particularly vulnerable population groups. The immediate implication of this study suggest adopting intensive conservation measures, through adoption of suitable silvicultural management practices, especially in degraded areas. On steep slopes, perennial grasses, hardy trees and shrubs should be planted. To meet the domestic needs of farmers like fuel, fodder and timber, the farmers should be encouraged for growing the multipurpose trees on field bunds of agriculture lands. These strategies will help in conserving the fragile agroforestry systems of Doon valley. Furthermore, there is a need to evolve different crops varieties which are suitable for intercultivation in such a system the trees mature and attains harvestable age. By combining the suitable complementary variety along with the agri-hortisilviculture system production of both grain and timber can be sustained.

\section{Conflict of interest statement}

Authors declare that they have no conflict of interest.

\section{Acknowledgement}

The authors are grateful to the Director, Dr.S.S.Sawhney, Uttaranchal College of Science and Technology, Dehradun (Uttarakhand) for providing necessary Laboratory conditions for conducting the study. The help extended by the farmers of the study area are duly acknowledged. 


\section{References}

Belsky, A.J., Amundson, R.G., Duxbury, J.M., Mhonga, T.K., 1989. The effect of trees on their physical, chemical, and biological environment in semi-arid Savana in Kenya. J. Appl. Ecol. 26, 1005-1024.

Bhardwaj, B.B., Gupta, S.R., 1993. Organic Matter Dynamics in a Populus deltoides agroforestry system. Int. J. Ecol. Environ. Sci. 19, 187-195.

Bijalwan, A., 2011. Productivity assessment of agricultural crops in existing agrihortisilvicultural system in mid hills of Central Western Himalaya, India. Afr. J. Agric. Res. 6(10), 2139- 2145.

Boscae, P.V., Gallagher, J.N.G., 1977. Weather, dry matter production and yield. In: Environment Effect on Crop Physiology (Eds.: Landsberg J.J., Cutting C.V.). Academic Press, London. pp.75-100.

Fay, C., Deforeta, H., Sarait, M., Tomich, T.P., 1998. A policy breakthrough for Indonesian farmers in the Krui dammar agroforesters. Agrofor. Today. 10(2), 25-26.

Gillespie, A.R., Jose, S., Mengel, D.B., Hoove, W.L., Pope, P.E., Street, J.R., Biehle, D.J., Stall, T., Benjamin, T.J., 2000. Defining competition vectors in a temperate alley cropping system in the Mid-Western USA. A production physiology. Agrofor. Syst. 48, 25-40.

Grossman, D., Grunow, J.D., Theron, G.K., 1980. Biomass cycles, accumulation rates and nutritional characteristics of grass layer plants in canopied and uncanopied subhabitates of Burka Savana. Prod. Grassland Soc. 15, 157-161.

Huxley, P.A., Darnhofer, T., Pinney, A., Akunda, E., Gatama, D., 1989. The tree/crop interface: a project designed to generate experimental methodology. Agroforestry. 2, 127-145.

Kessler, J.J., 1992. The influence of Karite (Vitellaria paradoxa) and nere (Parkia biglobosa) trees on sorghum production in Burkina Faso. Agrofor. Syst. 17, 97-118.

Khandakar, A.L., 1985. Screening genotypes of higher Harvest Index. Annual Report. pp.158-165.

Kohli, R. K., Singh, D., Rani, D., 1992. Allelopathic potential of volatile terpenes of Eucalyptus. In: Environmental Concerns in Rights-of-Way Management (Doucette, G.J., Seguin, C., Giuere, M.). Vice-presidence Environment Hydro-Quebec, Montreal, Canada. pp.102-106.

Kohli, R.K., Daizy, B., Singh, H.P., Batish, D., 1996. Performance of some winter season crops under Populus deltoides in simultaneous agroforestry system. In: IUFRO-DANES International Meeting on Resources Inventory Techniques to Support Agroforestry and Environment. D.A.V. College, Chandigarh, Punjab, (India), Oct. 1-3. pp.187-190.

Kumar, D., 2004. Studies on Production Potential of Different Crops under Poplar and Shisham based Agroforestry Systems. Ph.D. thesis, submitted to G. B. Pant University of Agriculture and Technology, Pantnagar, Uttarakhand.
Kushwaha, H.S., Mathur, G.M., 1995. Effect on yield of growing agriculture crops between multipurpose trees in an agroforestry system. Bhartiya Krishi Anusandhan Patrika. 10(3), 101-104.

Lakshmma, P., Rao, S.I.V., 1996. Response of Black Gram (Vigna mungo) to shade and naphthalene acetic acid. Ind. J. Plant Physiol. 1, 53-64.

Leaky, R.R.B., 1996. Definition of agroforestry revisited. Agrofor. Today. 8, 5-7.

Makundi, W.R., Sathaye, J.A., 2004. GHG mitigation potential and cost in tropical forestry relative role for agroforestry. Environ. Develop. Sustain. 6, 235-260.

Ong, C.K., Corlett, J.E., Singh, R., Black, C.K., 1991. Above and below ground interaction in Agroforestry Systems. Forest Ecol. Manage. 45, 45-57.

Puri, S., Bhargwa, K.S., 1992. Effects of tees on the yield of irrigated wheat crop in semiarid regions. Agrofor. Syst. 20(3), 229-241.

Puri, S., Kumar, A., 1995. Establishment of Prosopis cineraria (L.) Druce in the hot desert of India. New Forests. 27, 87-98.

Puri, S., Kumar, A., Singh, S., 1994. Productivity of Cicer arietinum (chickpea) under Prosopis cineraria agroforestry system in arid region of India. J. Arid Environ. 27, 87-98.

Puri, S., Swamy, S.L., Jaiswal, A.K. 2002. Evaluation of Populus deltoides clones under nursery, fields and agrisilviculture system in sub humid tropics of central India. New Forests. 23, 45-61.

Rao, G.R., Mishra, V.K., Gupta, B., Solanki, K.R., Kumar, A. 1998. Effect of widely spaced chir-pine trees non aboveground biomass of herbage layer and carrying capacity of the natural silvipastoral system in Northwest Himalayas. In: Multipurpose Tree Species Research (Eds.: Solanki, K.R., Bisaria, A.K., Handa, A.K.). Agrobioscience, Jodhpur, India. pp.270-275.

SAFE, 2004. Silvoarable Agroforestry for Europe. Accessed 28-9-2004.

Sanchez, P.A., 1995. Science in agroforestry. Agrofor. Systems. 30, 5-55.

Schroth, G., 1999. A review of below ground interactions in agroforestry, focusing on mechanisms and management options. Agrofor. Syst. 43, 5-34.

Swamy, S.L., Puri, S., 2005. Biomass Production and Csequestration of Gmelina arborea in plantation and agroforestry system in India. Agrofor. Syst. 64, 181-195.

Thakur, P.S., Dutt, V., 2003. Performance of wheat as alley crop grown with Morus alba hedgerows under rain fed conditions. Ind. J. Agrofor. 1\&2, 36-44.

Walker, J., Robertson, J.A., Penridge, L.A., Sharpe, P.J.H., 1986. Herbage response to tree thinning in Eucalyptus creba Woodland. Aust. J. Ecol. II, 135-140.

Yadav, J.P., Sharma, K.K., Khanna, P., 1993. Effects of Acacia nilotica on mustard crop. Agrofor. Syst. 2(1), 91-198.

\section{How to cite this article:}

Kaur, R., Lal, S., Bharti, U., 2016. Assessment of growth, biomass and productivity of Brassica campestris in an agroforestry system in Nagal Hatnala village, Dehradun (Uttarakhand). Int. J. Curr. Res. Biosci. Plant Biol. 3(8), 107-113. doi: http://dx.doi.org/10.20546/ijcrbp.2016.308.017 